\title{
Pigmented hypertrichotic dermatosis: manifestations of a rare syndrome
}

\author{
Sanae Sialiti, Siham Mansouri @ , Mehdi Khallaayoune, Karima Senouci
}

Department of DermatologyVenereology, CHU Ibn Sina, Rabat, Morocco, Rabat, Morocco

Correspondence to Dr Mehdi Khallaayoune; khallaayounemehdi@gmail.com

Accepted 18 March 2021

\section{DESCRIPTION}

A Moroccan 19-year-old patient, from a nonconsanguineous marriage, with a history of diabetes mellitus since the age of 8 years, presented at the age of 14 year with hypertrichosis and hyperpigmentation on the upper inner thighs, with involvement of the genitalia, trunk and limbs. The physical examination showed symmetrical pigmented hypertrichotic skin patches with induration of thighs and lower limbs with sparing of knees and popliteal fossa (figure 1), an orbital proptosis, musculoskeletal abnormalities including flat feet, scoliosis, clinodactyly and short stature, inguinal lymphadenopathy and hepatosplenomegaly.

The patient had low haemoglobin level at $9 \mathrm{~g} /$ $\mathrm{dL}$, elevated laboratory markers of inflammation included an elevated erythrocyte sedimentation rate (ESR), C-reactive protein (CRP) and raised serum immunoglobulin levels. He had had a positive anti-glutamic acid decarboxylase (anti-GAD) 65 antibody titre consistent. Biopsy specimens from the skin showed a chronic inflammatory perivascular infiltrate composed of lymphocytes and plasma cells, with no histological sign in favour of an autoimmune disease. No cardiac abnormalities were detected on echocardiography, ultrasound morphology of inguinal lymph nodes showed benign lymphadenopathy and radiography found pes planus (figure 2).

In view of associated cutaneous lesions and articular distortions, an $\mathrm{H}$ syndrome was suspected and genetic counselling was requested. The karyotype study did not demonstrate chromosomal abnormalities. Molecular analysis was carried out: the patient was not carrying the mutations already described in two Moroccan patients (c.243delA at exon 2 and $300+1 G>C$ at the second intron of the SLC29A3

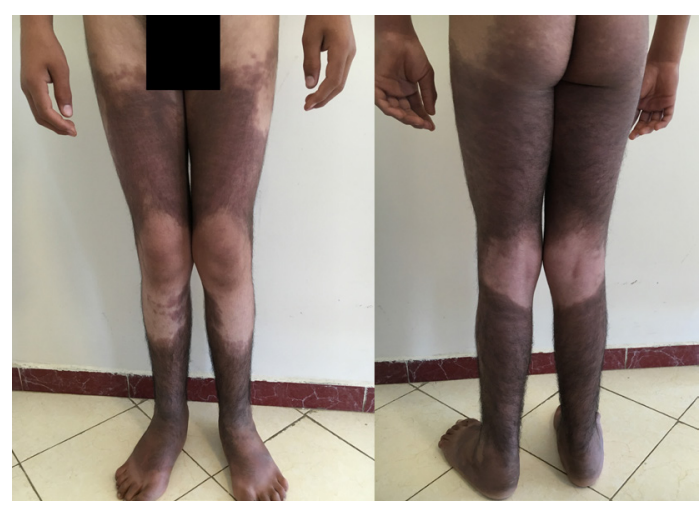

Figure 1 Hyperpigmented patches over thighs and limbs with associated hypertrichosis.

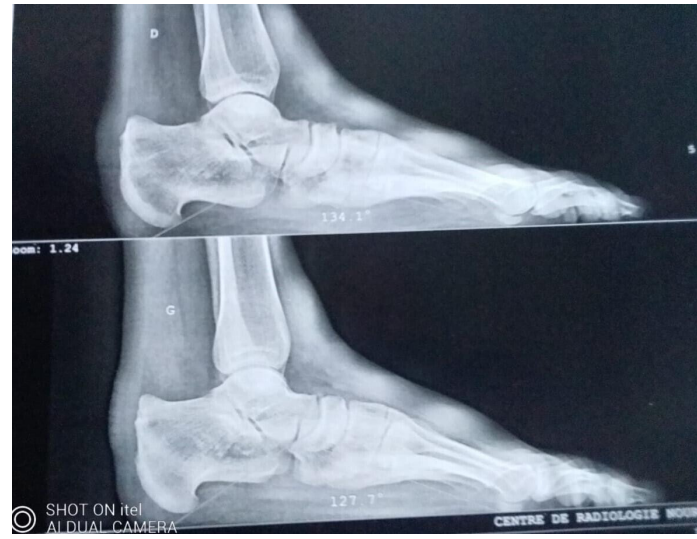

Figure 2 Weightbearing lateral view on radiography showing pes planus with angle of the longitudinal arch increased to more than $130^{\circ}$.

gene) and sequencing of the entire gene could not be achieved due to lack of resources. Nevertheless, the diagnosis of $\mathrm{H}$ syndrome was retained in light of the concordance with all the abnormalities outlined above.

First described in Israël in $2008,{ }^{1} \mathrm{H}$ syndrome is an autosomal recessive genodermatosis, whose manifestations are induced by mutations in the SLC29A3 gene encoding the nucleotide transport protein hENT3 and the underlying aetiology remains unknown. ${ }^{2}$ To date, 130 cases have been reported in the literature around the world and most of them come from low-income population groups where consanguinity is common. ${ }^{3}$ This entity is mainly characterised by hyperpigmented, indurated and hypertrichotic skin with variable systemic features including insulin-dependent diabetes mellitus (IDDM), sensorineural hearing loss, hepatosplenomegaly, hypogonadism, heart

\section{Learning points}

$\mathrm{H}$ syndrome is a rare autosomal recessive disorder which is one of a spectrum of diseases all resulting from a mutation in the SLC29A3 gene.

- Diagnosis should be made at an early stage to avoid unnecessary immunosuppressive treatment and provide an appropriate genetic counselling, moreover.

- It would be necessary to develop a simplified process to make genetic analysis more affordable for patients from low-income countries. 
anomalies, flexion contractures of the interphalangeal joints, short stature, hallux valgus, foot deformities, episcleritis, exophthalmos, lymphadenopathy and anaemia. Sometimes, certain of these conditions may lack in $85 \% .^{4}$

Reports have shown that along with $\mathrm{H}$ syndrome, three others diseases are caused by recessively mutations in the SLC29A3 gene: pigmented hypertrichosis with IDDM syndrome, familial Rosai-Dorfman disease and Faisalabad histiocytosis. ${ }^{5}$ Supportive care is recommended considering the absence of specific treatment.

Contributors SS: the doctor who took care of the patient and wrote the article. SM: the doctor who collaborated in the care of the patient and the design of the article. MK: the doctor who contributed in the design and execution of the paper. $\mathrm{KS}$ : the Dermatology Department Head who is responsible for all professional and scientific activities.

Funding The authors have not declared a specific grant for this research from any funding agency in the public, commercial or not-for-profit sectors.

Competing interests None declared.
Patient consent for publication Obtained.

Provenance and peer review Not commissioned; externally peer reviewed.

\section{ORCID iD}

Siham Mansouri http://orcid.org/0000-0002-5140-7607

\section{REFERENCES}

1 Molho-Pessach V, Agha Z, Aamar S, et al. The H syndrome: a genodermatosis characterized by indurated, hyperpigmented, and hypertrichotic skin with systemic manifestations. J Am Acad Dermatol 2008;59:79-85.

2 Ozlu C, Yesiltepe Mutlu G, Hatun S. A Turkish girl with H syndrome: stunted growth and development of autoimmune insulin dependent diabetes mellitus in the 6th year of diagnosis.. J Pediatr Endocrinol Metab 2019;32:89-93.

3 Bhatti S, Jamil A, Siddiqui SH, et al. The H syndrome: a genodermatosis. Cureus 2018; 10:e2763.

4 Molho-Pessach V, Ramot Y, Camille F, et al. H syndrome: the first 79 patients. J Am Acad Dermatol 2014;70:80-8.

5 de Jesus J, Imane Z, Senée V, et al. SLC29A3 mutation in a patient with syndromic diabetes with features of pigmented hypertrichotic dermatosis with insulin-dependent diabetes, H syndrome and Faisalabad histiocytosis. Diabetes Metab 2013;39:281-5.

Copyright 2021 BMJ Publishing Group. All rights reserved. For permission to reuse any of this content visit

https://www.bmi.com/company/products-services/rights-and-licensing/permissions/

BMJ Case Report Fellows may re-use this article for personal use and teaching without any further permission.

Become a Fellow of BMJ Case Reports today and you can:

- Submit as many cases as you like

Enjoy fast sympathetic peer review and rapid publication of accepted articles

- Access all the published articles

Re-use any of the published material for personal use and teaching without further permission

Customer Service

If you have any further queries about your subscription, please contact our customer services team on +44 (0) 2071111105 or via email at support@bmj.com.

Visit casereports.bmj.com for more articles like this and to become a Fellow 